\title{
A review of the most important natural antioxidants and effective medicinal plants in traditional medicine on prostate cancer and its disorders
}

\author{
Gholam Basati $^{1}{ }^{\mathbb{D}}$, Pardis Ghanadi² ${ }^{2}$ Saber Abbaszadeh ${ }^{3 *}$ \\ ${ }^{1}$ Biotechnology and Medicinal Plants Research Center, Ilam University of Medical Sciences, Ilam, Iran \\ 2Medical Student, Lorestan University of Medical Sciences, Khorramabad, Iran. \\ 3Student Research Committee, Lorestan University of Medical Sciences, Khorramabad, Iran
}

A R T I C L E I N F O

Article Type:

Review

\section{Article History:}

Received: 19 July 2019

Accepted: 28 October 2019

\section{Keywords:}

Prostate cancer

Inflammation

Prostatitis

Medicinal plants

Natural antioxidants

Herbal drugs

\begin{abstract}
A B S T R A C T
Herbal plants can be used to treat and prevent life-threatening diseases, such as prostate cancer, infections and other diseases. The findings from traditional medicine and the use of medicinal plants can help control and treat most problems due to prostate diseases. The aim of this study was to identify and report the most important medicinal plants that affect prostate disorders. Based on the results of the review of numerous articles indexed in the databases ISI, Scopus, PubMed, Google Scholar, etc., a number of plants have been reported to be used in the treatment and prevention of diseases, inflammation, infection, and cancer of the prostate gland. The plants include Panax ginseng, Arum palaestinum, Melissa officinalis, Syzygium paniculatum, Coptis chinensis, Embelia ribes, Scutellaria baicalensis, Tripterygium wilfordii, Salvia triloba, Ocimum tenuiflorum, Psidium guajava, Ganoderma lucidum, Litchi chinensis, Saussurea costus, Andrographis paniculata, Magnolia officinalis and Prunus africana. Phytochemical investigations have examined the therapeutic effects of medicinal plants effective on prostate cancer and their possible mechanisms of action and clinical effects as well as the use of active flavonoids in production of herbal drugs. Due to the active ingredients and important flavonoids of these plants, they can be used in production of herbal drugs that prevent and treat infections, inflammation and cancer of the prostate gland, and reduce the metastasis of prostate cancer cells, reducing the patients' suffering and pain.
\end{abstract}

Implication for health policy/practice/research/medical education:

Medicinal plants presented in this review might be used effectively for some prostate disorders. Cautious about drug interaction and side effects of medicinal plants is very important.

Please cite this paper as: Basati G, Ghanadi P, Abbaszadeh S. A review of the most important natural antioxidants and effective medicinal plants in traditional medicine on prostate cancer and its disorders. J Herbmed Pharmacol. 2020;9(2):112-120. doi: 10.34172/jhp.2020.15.

\section{Introduction}

The prostate gland, as age increases, may be affected by many diseases, including benign prostatic hyperplasia $(\mathrm{BPH})$ and prostate cancer, due to impaired normal growth of the gland (1). Prostate cancer is a condition in which malignant cells originate in prostate tissues and irregularly proliferate, resulting in an increase in volume of each of the cellular components of the prostate gland $(2,3)$. Prostate cancer is one of the most common cancers and the second leading cause of cancer deaths in men $(4,5)$. Although prostate cancer is more common in older men, studies have shown that one third of men in the 30's and 40's have histological evidence of prostate adenocarcinoma (6). The formation of a tumor in the prostate is related to several factors such as age, race, diet, heredity, and the environment (7). In addition, inflammation is also a major contributor to prostate diseases and may play a role in the growth of tumor cells. Prostate cancer seems to be partly related to genetics, but environmental factors are also involved $(8,9)$. Prostate diseases have adverse effects on fertility and also cause urinary problems due to the anatomical condition of the prostate $(10,11)$. Prostatitis is classified as acute, chronic, asymptomatic inflammatory (chronic pelvic pain syndrome), and chronic bacterial. 
Prostatitis may develop at any ages $(12,13)$. Several studies in different countries have confirmed the beneficial effects of herbal therapy on prostate cancer and other diseases (14). In developed countries, prostate cancer is the second leading cancer in men, so that one out of every six men develops the cancer (15). With the increasing prevalence of prostate cancer deaths and the inefficacy of chemotherapy and radiation therapy in advanced forms of this cancer, new methods are needed to control this cancer (16). BPH is the fourth leading disease in men over the age of 50 (17). As the age advances, the prevalence of $\mathrm{BPH}$ increases (18-22). Most of the plants' properties are related to antioxidant activity (23), which is mainly due to the presence of phenolic compounds (24). However, other compounds are likely to be involved in the plants' activities. Nettle is known to exhibit positive effect on the treatment of BPH (25). The main activity of nettle seems to be exerted by disrupting dihydrotestosterone binding to cytosol and nuclear receptors (26), explaining the role of the plant in preventing prostate cancer. A recent study showed that $20 \%$ extract of the nettle had specific antiproliferative effects on the epithelial and stromal cells of the prostate $(27,28)$. There is a compound in the garlic that has been reported to inhibit the growth of prostate cancer cells in vitro. Garlic can counteract cancer causing agents. In garlic, the compound S-allyl cysteine has high antitumor properties, thus converting remaining testosterone products into low-risk materials (29-31). A review study has shown that Allium can effectively inhibit proliferation of the LNCaP prostate cancer cells (32). Green tea can have inhibitory effects on prostate cancer. Studies on rats have shown that green tea is able to inhibit the enzyme 5-alpha reductase. This enzyme is a conversion factor of testosterone to dihydrotestosterone, which is a carcinogenic agent in the prostate (33). Researchers have found that the strongest of these compounds in the green tea is epigallocatechin-3-gallate (34). Epigallocatechin3 -gallate and other green tea compounds inhibit the activity of an enzyme called proteasome. Proteasome is a key factor in the development of prostate cancer (35). Studies have shown that curcumin blocks the growth of the prostate cancer cell by inhibiting the activity of the enzyme tyrosine kinase in the epidermal growth factor receptor (36). One study demonstrated that curcumin is effective in treating androgen dependent prostate cancer (37). In a recent study, curcumin was observed to inhibit prostate cancer cells, and completed this action by blocking the effects of factors called AP- 6 and NFKappaB (38). A study on animal tissue reported evidence for the positive effect of the Pygeum africanum extract on inflammation involved in the development of BPH (39). A clinical study has shown that $P$. africanum can improve enlarged prostate gland and prevent development of incidental prostate cancer (40-42). A study suggested that the therapeutic and preventive effects of hydroalcoholic extract of Thymus vulgaris on precancerous lesions and squamous cell carcinoma of the prostate gland observed in Wistar rats can be attributed to thymol and carvacrol. Flavonoids are other compounds in the hydroalcoholic extract of Thymus vulgaris which have anti-cancer effects (43). The aim of this study was to identify and report the most important medicinal plants that affect prostate disorder.

\section{Materials and Methods}

The information used in this review was obtained from the articles indexed in the databases Iran Medex, Irandoc, PubMed, Scopus, Web of Science, Scientific Information Database, Google Scholar, Magiran, etc. using the search terms prostate cancer, prostate inflammation and diseases, prostatitis, medicinal plants, medicinal plants effective on prostate cancer, medicinal plants effective on prostate inflammation and prostatitis, mechanism of action of medicinal plants effective on prostate cancer, and antioxidant and anticancer effects of extracts and essential oils of medicinal plants effective on prostate diseases. In this study, 165 articles were reviewed. After the initial review, 80 articles were found to address the subject of our review. Irrelevant articles were also excluded. Finally, 80 articles related to the purpose of our review published by 2019 were included in the final analysis.

\section{Results}

The medicinal plants and their natural antioxidants, which we examined in this study, effectively influence the treatment and prevention of prostate diseases and cancer and prostatitis via the potential mechanisms reported (Table 1). Based on the results of a review of numerous articles, some of the most important plants for the treatment and prevention of prostate cancer, and infections and inflammation of the prostate gland include Panax ginseng (Asian ginseng), Arum palaestinum (black calla), Melissa officinalis (common balm), Syzygium paniculatum (magenta cherry), Coptis chinensis (magenta lilly pilly), Embelia ribes (false black pepper), Scutellaria baicalensis (Baikal skullcap), Tripterygium wilfordii (thunder god vine), Salvia triloba (Greek sage), Ocimum tenuiflorum (holy basil), Psidium guajava (common guava), Ganoderma lucidum (mushroom ), Litchi chinensis (Lychee), Saussurea costus (costus), Andrographis paniculata (green chiretta), Magnolia officinalis (houpu magnolia) and Prunus Africana (African cherry). The supplementary information and detailed therapeutic action mechanisms of medicinal plants are shown in Table 1.

The most important active ingredients and important flavonoids in these plants include saponins, lignans, coumarins, flavones, phenolic compounds, Dammarane-type saponin, quercetin, total flavonoids and phenolics, isoquercitrin, flavan-3-ol, cyanidin- 
Table 1. The mechanisms of antioxidant and anticancer actions of the most important medicinal plants effective on prostate diseases and prostate cancer

\begin{tabular}{|c|c|c|c|c|c|c|}
\hline Scientific name & Family name & Part of plant & Common name & Study model & $\begin{array}{l}\text { The mechanisms of antioxidant and anticancer actions of the most important medicinal plants effective on prostate diseases and } \\
\text { prostate cancer }\end{array}$ & Ref. \\
\hline Panax ginseng & Araliaceae & Root & Ginseng & Rat & $\begin{array}{l}\text { The group treated with } P \text {. ginseng showed significantly lesser prostate size and weight than the testosterone-induced BPH group. In } \\
\text { addition, } P \text {. ginseng decreased the mRNA expression of Adra1d as well as the expression of EGFR and BCL2 in prostate tissue. }\end{array}$ & (44) \\
\hline Androsace & Primulaceae & Aerial part & rockjasmine & Rat & $\begin{array}{l}\text { The flavonoids isolated from this plant, oleanane-type triterpene saponin, increase cytotoxicity and alter the morphology of the cell as } \\
\text { well as the sub-GO/G1 phase, leading to an increase in apoptosis in prostate cancer cells and other cancerous tissues. It also induces the } \\
\text { death of autophagy of the cell by converting LC3B-I to LC3B-II and producing autophagy vaccines. Flavonoids in this plant also inhibit PI3k, } \\
\text { Akt, mTOR, and inhibit migration and invasion of cells. }\end{array}$ & (46) \\
\hline $\begin{array}{l}\text { Melissa } \\
\text { officinalis }\end{array}$ & Lamiaceae & Leaves & Lemon balm & Human & $\begin{array}{l}\text { Polyphenols of hydroalcoholic extract of this plant are used in the treatment of prostate cancer of } 100 \mu \mathrm{g} / \mathrm{mL} \text {. Extract of this plant } \\
\text { inhibits the expression of Boc2, Her2, VEGF-A and hTERT oncogenes in prostate cancer. Expression of her2 acts as a mitochondria (PI3K } \\
\text { dependent activation of AKT). }\end{array}$ & (47) \\
\hline Artemisia & Asteraceae & $\begin{array}{l}\text { Aerial part } \\
\text { and root }\end{array}$ & Wormwood & Human & $\begin{array}{l}\text { Scoparone is a coumarin present in the extract of this plant. It is an anti-inflammatory compound that carries NF-kB transcription, and the } \\
\text { extract of this plant at a concentration of } 41.3 \mu \mathrm{mol} / \mathrm{L} \text { at this concentration causes a stop in the G1 phase of the cell cycle and Prevents } \\
\text { proliferation of prostate cancer cells, suppressed IL- } 6 \text {-stimulated STAT3 transcriptional activity Controls the transcriptional activity of NF- } \\
\text { KB stimulated by TNF- } \alpha \text {. The expression of mRNA reduces the STAT3 genes. }\end{array}$ & (48) \\
\hline Geissospermum & Apocynaceae & Stem crust & Dogbane & Human & $\begin{array}{l}\text { Extract from this skin of p21, p27 and PCNA, Cyclin A and Cyclin D1 inhibitors. At a concentration of } 125 \mu \mathrm{g} / \mathrm{mL}, \mathrm{G} 1 \text { stops cell cycle and } \\
\text { apoptosis. The extract of this plant induces high preopaptotic BAX regulation and decreases the expression of Bcl-2, Bcl-xL, and XIAP anti- } \\
\text { apoptotic expressions. Immigration and invasion of prostate cancer cells block and inhibit the phosphorylation of AKT and NFKB / p65 } \\
\text { and the activity of NFKB DNA binding, and TNFa inhibits NFKB/p65 placement into the nucleus, transcribes it, and inhibits MMP9 activity. } \\
\text { NFKB/p65 involved in the proliferation of Cyclin D1),), survival (Bcl-2, Bcl-xL, and XIAP), and metastasis (VEGFa, MMP9, and GROa/ CXCL1). }\end{array}$ & (49) \\
\hline $\begin{array}{l}\text { Syzygium } \\
\text { paniculatum }\end{array}$ & Myrtaceae & Aerial part & Magenta cherry & Human & $\begin{array}{l}\text { Flavonoid Tubeimoside-1 (TBMS1), a triterpenoid saponin is extracted from this plant, and at concentrations }(5-100 \mu \mathrm{mol} / \mathrm{L}) \text { induces } \\
\text { apoptosis and stops in the G0 and G1 phases. This family of compounds activates the stress-activated MAPK proteins and induces } \\
\text { apoptosis signal-regulating kinase } 1 \text { (ASK-1) phosphorylation and induces apoptosis due to oxidative stress. }\end{array}$ & (50) \\
\hline Acanthopanax & Araliaceae & $\begin{array}{l}\text { Leaves and } \\
\text { stems }\end{array}$ & Eleutherococcus. & Human & $\begin{array}{l}\text { Ethyl acetate extracts of this plant suppress the NFKB transcription activity and increase the amount of caspase } 3 \text { and increase the } \\
\text { amount of phospho-Erk1/2 and phospho-Akt. }(80 \mu \mathrm{g} / \mathrm{mL}) \text { from the leaf and stem of this extract plant. }\end{array}$ & (51) \\
\hline Coptis chinensis & Ranunculaceae & Rhizome & $\begin{array}{l}\text { Chinese } \\
\text { goldthread }\end{array}$ & Human & $\begin{array}{l}\text { The compound in the rhizome (the stems of the underground) is called Berberine, which is used at various concentrations of 20-100-200 } \\
\mu \mathrm{M} \text {. At a concentration of 20-100 } \mu \mathrm{M} \text {, it reduces the proliferation of cancer cells and at a concentration of } 20 \mu \mathrm{M} \text { survival decreases. At } \\
\text { a concentration of } 100 \mu \mathrm{M} \text {, it causes cellular stagnation in the } \mathrm{G} 1 \text { phase and a decrease in the } \mathrm{G} 2 / \mathrm{m} \text { phase, and increases apoptosis and } \\
\text { decreases expression of the PSA. It inhibits EGFR activation and reduces the expression and activation of EGF-induced EGF. }\end{array}$ & (52) \\
\hline Embelia ribes & Primulaceae & $\begin{array}{l}\text { Fruit and } \\
\text { stems }\end{array}$ & $\begin{array}{l}\text { White-flowered } \\
\text { embelia }\end{array}$ & Human & $\begin{array}{l}\text { The combination of this plant Embelin, which inhibits the X-linked inhibitor of apoptosis protein (XIAP), induces apoptosis by TNF } \alpha \text { and } \\
\text { the TNF-associated apoptosis-inducing ligand (TRAIL). At a concentration of } 10-20 \mu \mathrm{M} \text {, it causes a stop in the S-cycle of the cell cycle, and } \\
\text { it can also stop in the G2/M phase and stimulate Caspase } 3 \text { activity. }\end{array}$ & (53) \\
\hline
\end{tabular}


Table 1. Continued

\begin{tabular}{|c|c|c|c|c|c|c|}
\hline Scientific name & Family name & Part of plant & Common name & Study model & $\begin{array}{l}\text { The mechanisms of antioxidant and anticancer actions of the most important medicinal plants effective on prostate diseases and } \\
\text { prostate cancer }\end{array}$ & Ref. \\
\hline $\begin{array}{l}\text { Scutellaria } \\
\text { baicalensis }\end{array}$ & Lamiaceae & Root & Baikal skullcap & Human & $\begin{array}{l}\text { In concentration } 200 \mathrm{mg} / \mathrm{kg} \text { aqueous extract of the plant has effects on cell proliferation, cyclooxygenase 2, decreased prostaglandin E2, } \\
\text { and cyclins / cdks pathway, decreasing PSA. It decreases the expression of cyclin D1 and causes stopping in G1 phase and CDK1 inhibitors } \\
\text { and kinase activity Causing G 2/M to stop. }\end{array}$ & (54) \\
\hline $\begin{array}{l}\text { Tripterygium } \\
\text { wilfordii }\end{array}$ & Celastraceae & Root crust & $\begin{array}{l}\text { Thunder god } \\
\text { vine }\end{array}$ & Human & $\begin{array}{l}\text { The root skin of this plant has antitumor activity and decreases the survival of prostate cancer cells, both in dependent and non- } \\
\text { androgenic androgens, and suppresses migration and invasion in a non-toxic dose of less than } 1 \mu \mathrm{M} \text { and proliferation at } 0.5 \mu \mathrm{M} \text {. This } \\
\text { combination also induces apoptosis (sub-G1 population increase) and Mcl-1 modulation and induction of stopping in the G2/M phase, } \\
\text { increases the activity of caspase enzymes } 3-9 \mathrm{~m} \text {, blocking the activity of NF-kb and cytosolic IkB degeneration he does. }\end{array}$ & (53) \\
\hline $\begin{array}{l}\text { Ocimum } \\
\text { tenuiflorum }\end{array}$ & Lamiaceae & Leaves & tulasi & Human & $\begin{array}{l}\text { Leaf ethanolic extract }(25,50 \text { and } 100 \mathrm{lg} / \mathrm{mL}) \text { reduces the survival of cancer cells and also increases the level of caspase- } 9 \text { and caspase-3 } \\
\text { reduction of Bcl-2, increasing the cleaved PARP in the concentration-dependent manner. }\end{array}$ & (56) \\
\hline $\begin{array}{l}\text { Psidium } \\
\text { guajava }\end{array}$ & Myrtaceae & Leaves & Lemon guava & Human & $\begin{array}{l}\text { The methanolic extract of this plant, including triterpenoids, flavonoids, essential oil, and tannins, suppresses PIJK/AKT/mTOR/S6K1 and } \\
\text { mitogen-activated protein kinases (MAPKs), also lowers the levels of proteins involved in cell proliferation, Anti-apoptotic and metastatic, } \\
\text { at a concentration of } 50 \mu \mathrm{g} / \mathrm{mL} \text {, has cytotoxicity and induces cell death, and reduces cell survival by stopping the sub-G1 phase cell cycle. } \\
\text { At concentrations of } 100-150 \mu \mathrm{g} / \mathrm{mL} \text {, fractionation of procaspase- } 9 \text { and PARP and induction of procaspase-3-8 result. It also suppresses } \\
\text { cell cycle protein (cyclin D1) and proteins associated with metastases and angiogenesis of COX-2 and VEGF, and it inhibits nitric oxide } \\
\text { synthase and produces COX-2 through low levels of NFkB, as well as ERK and JNK phosphorylation and Suppresses p38. }\end{array}$ & (57) \\
\hline Fraxinus & Oleaceae & Whole plant & Ash & Human & $\begin{array}{l}\text { The compound in this plant is nummularic acid, which is a triterpenoid. } 20 \mu \mathrm{M} \text { and } 40 \mu \mathrm{M} \text { is anticologenic and antiproliferative, causes } \\
\text { apoptosis and induces PARP and partition of caspase } 3 \text {, also induces phosphorylation of Thr172 in the alpha AMPK subunit and also } \\
\text { reduces mTORC1. }\end{array}$ & (58) \\
\hline $\begin{array}{l}\text { Ganoderma } \\
\text { lucidum }\end{array}$ & Ganodermataceae & Whole plant & Ganoderma. & Human & $\begin{array}{l}\text { At concentrations }(0.5-2.5 \mathrm{mg} / \mathrm{mL}) \text { from the plant's extract, it can inhibit invasive prostate cancer by decreasing the expression of NF- } \\
\text { kappaB, the activator of plasminogen yerokinase (uPA) and uPA receptor. Meanwhile, G. lucidum }(0.125-0.5 \mathrm{mg} / \mathrm{mL} \text { ) can cause apoptosis, } \\
\text { inhibit cell proliferation and suppress the migration of highly invasive PK-3 cancer cells, as well as angiogenesis-dependent prostate } \\
\text { cancer with MAPK and Akt signaling modulation Controlling PC-3 cells The results showed that G. lucidum had the efficacy of clinical } \\
\text { treatment for the treatment of prostate cancer. }\end{array}$ & (59) \\
\hline
\end{tabular}


Table 1. Continued

Scientific name Family name

Part of plant

Common nam

Study mode

Litchi chinensis Sapindaceae
Lychee

Human
The mechanisms of a prostate cancer

Seed extract of this plant has different drug effects, including significant cellular and clonogenic cellular and cellular survival of prostate cancer PC-3, DU145, RM-1 and C4-2B by dose-dependent method (31-25 g/mL) and induction of cell apoptosis and end-of-cycle cycles Cells in the G1 / S phase by disabling the signaling pathway of the protein kinase B (Akt or PKB), in addition, the extracts significantly reduce cell migration and invasion by reducing the phenotypic change of the epithelial prostate mesenchymal cancer.

Hexane extracts of this plant inhibit proliferation inducing epidermal growth factor (EGF) induction of prostate cancer metastases DU145 e-dependent manner $(1-4 \mathrm{~g} / \mathrm{mL})$, while plant reduced the metalloproteinase (MMP)-9 matrix and the metalloproteinase secretion inhibitor (TIMP-1), but the level of TIMP-2 (59) increased in the absence or presence of EGF. The results showed that hexane extracts $\mathrm{S}$. lappa may be used as anti-metastases for the treatment of prostate cancer.

\begin{tabular}{lllll}
$\begin{array}{l}\text { Saussurea } \\
\text { costus }\end{array}$ & Asteraceae & Aerial part & Costus & Human \\
\hline $\begin{array}{l}\text { Andrographis } \\
\text { paniculata }\end{array}$ & Acanthaceae & Whole plant & Andrographis & Human \\
\hline
\end{tabular}

Magnolia
officinalis Magnoliaceae $\quad$ Leaves Houpu magnolia Human

Flavonoids derived from this plant, called diterpenoid lactone (1-20 $\mu \mathrm{M})$, which can inhibit IL-6-induced signaling in an animal model, inducing a transducer of transcriptional activator and transcription (STAT3) and extracellular signal phosphorylation Regulator (ERK). At (59) the same time, it can prevent the survival of cells and inducing apoptosis of cancer cells of the prostate cancer PC3 and DU145.

Honokiol is a compound that is available in this plant and is dosed $(20-60 \mu \mathrm{M})$. It reduces the survival of PC-3 and LNCaP human prostate cancer cells by stopping the GO/G1 cell cycle and inducing apoptosis $(5-20 \mu \mathrm{M})$ in PCa cells by activating 9/3.8, and polymorphizes poly- (59) adenosine diphosphate ribose and also leads to ROS-mediated cytoprotective autophagy.

The most important ingredient in this plant is pentacyclic triterpenoid, which prevents the survival and proliferation of prostate cancer cells by inducing apoptosis and interacting with the microenvironment of the tumor through multiple modulation of signal transmission pathways. This combination prevents cell survival and proliferation and Promoting cell apoptosis and stopping the cell cycle in the G0 / G1 phase in prostate cancer. Its anticancer effects are as a result of kinase (PI3K) phosphoinositide 3- and protein kinase B (Akt) pathway suppression and induces antitumor activity by interfering with the metabolic pathway in cancer cells through the activation of the 5-AMP (AMPK) enzyme -activated protein kinase.

Atraric acid is a significant phenolic and sterile compound in this plant that has potent anti-androgenic activity that decreases the proliferation of cancer cells (prostate) and affects androgenic receptors.

$\begin{aligned} & \text { Prunus } \\ & \text { africana }\end{aligned}$ Rosaceae Leaf $\quad$ Prunus africana Human


3-glucoside, hypoglycin A, 2,6-dimethoxyphenol, syringol, 2-methoxyphenol, guaiacol,3,5-dimethoxy-4hydroxytoluene, baicalin, wogonin, norwogonin, oroxylin A, $\beta$-sitosterol, apigenin, luteolin, quercetin-3-O- $\beta$ - glucoside, daucosterol, 2,6-dimethoxy-I,4-benzoquinone. The supplementary information and detailed the most important active ingredients and important flavonoids of medicinal plants are shown in Table 2.

Table 2. Effective bioactive compounds of the herbal plants

\begin{tabular}{|c|c|c|}
\hline Scientific name & Effective material & Ref. \\
\hline Panax ginseng & $\begin{array}{l}\text { 5, 7-Dihydroxy-8-methoxyl flavone, ginsenoside Rs2, quinquenoside R1, ginsenoside Rs1, notoginsenoside Fe, } \\
\text { ginsenoside Rd2, gypenosiden IX, saponin }\end{array}$ & (45) \\
\hline Arum palaestinum & $\begin{array}{l}\text { sovanillin, linolenic acid, } \beta \text {-sitosterol, apigenin, luteolin, quercetin, quercetin-3-O- } \beta \text {-glucoside, vitexin, isoorientin, } \\
\text { esculin, caffeic, ferulic acids }\end{array}$ & (45) \\
\hline Androsace & $\begin{array}{l}\text { Saponin, kaempferol 3-O-(3-O-acetyl-)-alpha-L-rhamnopyranoside, kaempferol 3-O-(2-O-acetyl-)-alpha-L- } \\
\text { rhamnopyranoside, kaempferol 7-O-alpha-L-rhamnopyranoside, kaempferol 3-O-alpha-L-rhamnopyranoside, } \\
\text { kaempferol 3-O-beta-D-glucopyranoside, kaempferol 3-O-(3-O-acetyl-)-a-L-rhamnopyranosyl-7-O-alpha-L- } \\
\text { rhamnopyranoside, kaempferml 3-O-(4-O-acetyl-)-alpha-L-rhamnopyranosyl-7-O-alpha-L-rhamnopyranoside, } \\
\text { quercetin 3-O-alpha-L- rhamnopyranoside, quercetin 3-O-beta-D-glucopyranoside, myricetin 3-O-beta-D- } \\
\text { glucopyranoside }\end{array}$ & $(46)$ \\
\hline Melissa officinalis & Alpha-pinene, borneol, camphene, camphor, verbenone, bornyl-acetate. & $(47)$ \\
\hline Artemisia annua & Germacrene $D, \beta$-pinene, $\nu$-humulene, d-galacturonic acid, $d$-galactose, $d$-xylose . & $(48)$ \\
\hline Geissospermum & $\begin{array}{l}\text { Alkaloids O-demethylaspidospermine, flavopereirine, alkaloid geissoschizoline, geissoschizoline N(4)-oxide, } \\
\text { 1,2-dehydrogeissoschizoline }\end{array}$ & (49) \\
\hline Syzygium paniculatum & $\begin{array}{l}\alpha \text {-Pinene, } n \text {-hexadecanoic acid, limonene, farnesol, } \beta \text {-ocimene, citronellol, linoleic acid, octahydro-1,4-dimethyl } \\
\text { azulene, citral, phytol, linolenic acid, thymol }\end{array}$ & $(50)$ \\
\hline Acanthopanax & $\begin{array}{l}\text { Triterpenoid saponins, lignans, coumarins, flavones, phenolic compounds, acantrifoic acid C, acantrifoic acid D, } \\
\text { triterpenoids }\end{array}$ & (51) \\
\hline Coptis chinensis & $\begin{array}{l}\text { 8,9-dihydroxy-1,5,6, 10b-tetrahydro-2H-pyrrolo[2,1 -alpha] isoquinolin-3-one,(+/-) -5,5'-dimethoxy- } \\
\text { lariciresinol,3,4-dihydroxy-phenylethylalcohol, methyl-5-O-feruloylquinate, ethyl-5-O- feruloylquinate, apocynol. }\end{array}$ & $(52)$ \\
\hline Embelia ribes & Quinones, alkaloids, terpenoids, steroids, flavones & $(53)$ \\
\hline Scutellaria baicalensis & baicalein, baicalin, wogonin, norwogonin, oroxylin $A, \beta$-sitosterol & $(54)$ \\
\hline Tripterygium wilfordii & Alkaloids, Celastrol, pentacyclic triterpenoid, triptolide, a diterpene triepoxide & $(53)$ \\
\hline Salvia fruticosa & $\begin{array}{l}\text { 1,8 - cineole, } \beta \text {-pinene, } \beta \text {-caryophyllene, camphor, flavonoids hispidulin, salvigenin and cirsimaritin, carnosic } \\
\text { acid, carnosol, } 12 \text {-methoxycarnosic acid. }\end{array}$ & $(55)$ \\
\hline Ocimum tenuiflorum & $\begin{array}{l}\text { Oleanolic acid, ursolic acid, rosmarinic acid, eugenol, carvacrol, linalool, } \beta \text {-caryophyllene, essential oil, eugenol, } \\
\beta \text {-elemene, } \beta \text {-caryophyllene, germacrene, terpenes. }\end{array}$ & $(56)$ \\
\hline Psidium guajava & $\begin{array}{l}\text { Triterpenoids, flavonoids, essential oil, and tannins, morin-3-O-lyxoside, morin-3-O-arabinoside, quercetin and } \\
\text { quercetin-3-O-arabinoside. }\end{array}$ & (57) \\
\hline Fraxinus spp. & $\begin{array}{l}\text { Nummularic acid, 8- hydroxy-12-oxoabieta-9,13-dien-20-oic, 20-lactone, 6beta-hydroxyfcrruginol,pisiferic } \\
\text { acid, pisiferal(4),(+)-7-dehydroabiet6none, 1-oxomiltirone, subdigitatone, linarionoside B,(3R,9R)-3-hydroxy- } \\
\text { 7,8-dihydro-beta-ionol 9-O-beta-D-apiofuranosyl-(1-->6)-beta-D-glucopyranoside, ursolic acid, betulinic } \\
\text { acid, euscaphic acid, syringaresinol,fraxiresinol, (1-hydroxysyringaresinol, pinoresinol, medioresinol, } \\
\text { 8-acetoxypinoresinol, epipinoresinol, (+)-1-hydroxypinoresinol 4"-O-beta-D-glucopyranoside,(+)-syringaresinol } \\
\text { O-beta-D-glucopyranoside, liriodendrin, ehletianol D, icariside E5(29) (-)-(7R, 8R)-threo-1-C-syringylglycerol,sin } \\
\text { apyladehyde(38), trans-p-hydroxycinnamaldehyde, syringic acid, vanilic acid, vanillin, 4-hydroxy-benzaldehyde, } \\
\text { (24R)-24-ethyl-5alpha-cholestane-3beta,5,6beta-triol, beta-sitosterol, daucosterol, 2,6-dimethoxy-I,4- } \\
\text { benzoquinone. }\end{array}$ & $(58)$ \\
\hline Ganoderma lucidum & $\begin{array}{l}\text { Steroid hormones, polysaccharides, beta-glucan, coumarin, mannitol, alkaloids. Sterols ganoderol, ganoderenic } \\
\text { acid, ganoderiol, ganodermanontriol, lucidadiol, ganodermadiol. }\end{array}$ & (59) \\
\hline Litchi chinensis & $\begin{array}{l}\text { Polyphenols, flavan-3-ol, cyanidin-3-glucoside, hypoglycin A, 2,6-dimethoxyphenol, syringol, 2-methoxyphenol, } \\
\text { guaiacol,3,5-dimethoxy-4-hydroxytoluene }\end{array}$ & (59) \\
\hline Saussurea costus & Costunolide, dehydrocostus lactone, scopoletin, $\alpha$-linolenic acid & $(59)$ \\
\hline $\begin{array}{l}\text { Andrographis } \\
\text { paniculata }\end{array}$ & $\begin{array}{l}\text { diterpenoid lactone, 14-Deoxy-11-dehydroandrographolide, 5-Hydroxy-7,8,2',3'-tetramethoxyflavone, } \\
\text { andrographine, andrographolide, neoandrographolide, panicoline, paniculide-A, paniculide-B, paniculide-C }\end{array}$ & (59) \\
\hline Magnolia officinalis & magnolol, honokiol, saponins, lignans, coumarins, flavones, phenolic compounds. & $(59)$ \\
\hline Prunus africana & pentacyclic triterpenoid, magnoloside B, magnoloside A, magnoloside F, magnolol, obvatol and honokiol. & $(60)$ \\
\hline
\end{tabular}




\section{Discussion}

Due to the numerous complications of anticancer drugs and chemotherapy such as dizziness, headache, weakness, tachycardia, hypotension and high cost of treatment with anti-prostate cancer drugs, most people today tend to use plant products. The therapeutic effects of many medicinal plants in many diseases and cancers have been proven (61-63), among which Panax ginseng, Arum palaestinum, Androsace, Melissa officinalis, Artemisia, Geissospermum, Syzygium paniculatum, Acanthopanax, Coptis chinensis, Embelia ribes, Scutellaria baicalensis, Tripterygium wilfordii, Salvia fruticosa, Ocimum tenuiflorum, Psidium guajava, Fraxinus, Ganoderma lucidum, Litchi chinensis, Saussurea costus, Andrographis paniculata, Magnolia officinalis, Prunus africana have the greatest impact on prostate diseases.

A variety of vitamins and antioxidant substances also play a significant role in improving prostate function and are used in many natural products to control prostate problems. Anticancer, antioxidant compounds in the diet, such as tocopherols and carotenoids, have been proven in many clinical trials and published. Antioxidants can stimulate the immune system to locate the tumor and destroy its cells or inhibit angiogenesis. It also causes a widespread expression of the p53 gene, which is a suppressor of tumor cells. According to studies, consumption of herbs effective in treating prostate diseases plays an important part in treating the diseases due to fewer side effects and antioxidant and regulator effects. It seems that the herbal products of interest can be effective in controlling the abnormal growth of precancerous lesions and prostate carcinoma (64-69). Medicinal plants with herbal antioxidants and active ingredients have their effects on the treatment of diseases (70-72). In this review article, potent biologically active antioxidant compounds from natural sources and medicinal plants with substantial medical and pharmaceutical effects in the treatment of prostate diseases and cancer were discussed. The results of the phytochemical studies have indicated the antioxidant, anticancer and antimicrobial properties of the above-mentioned medicinal plants may be due to biologically active compounds and active flavonoids, such as the active ingredients saponins, lignans, coumarins, phenolic compounds, Dammaranetype saponin, flavones, quercetin, total flavonoids and phenolics, flavan-3-ol, cyanidin-3-glucoside, isoquercitrin, hypoglycin A, 2,6-dimethoxyphenol, syringol, 2-methoxyphenol, baicalin, wogonin, guaiacol, 3,5-dimethoxy-4-hydroxytoluene, norwogonin, oroxylin A, $\beta$-sitosterol, quercetin-3-O- $\beta$-glucoside, daucosterol, apigenin, luteolin and 2,6-dimethoxy-I,4-benzoquinone. This review highlights some of therapeutic methods and medicinal plants recommended by traditional medicine across the world that have anticancer effect and are effective on prostate diseases and cancer.
The present study sought to introduce the mechanism and the effect of some common herbal drugs with special antioxidant effects, so that they can be used as preventive and therapeutic drug supplements in prostate diseases and tumors in humans. The medicinal plants can also be used to deliver pharmaceutical supplements in medicine due to the presence of antioxidant compounds, biologically active compounds, flavonoids, etc.

\section{Authors' contributions}

SA prepared the manuscript while GHB and MSH edited the manuscript. All authors reviewed, commented and approved the final draft.

\section{Conflict of interests}

The authors have no conflict of interests to declare regarding the publication of this paper.

\section{Ethical considerations}

Ethical issues have been observed by the authors.

\section{Funding/Support}

No support for this review article. The author declares that the work was self-funded.

\section{References}

1. McKee TC, Tricoli JV. Epigenetics in prostate cancer. Methods Mol Biol. 2015;1238:217-34. doi: 10.1007/978-14939-1804-1_11.

2. Powell IJ. Epidemiology and pathophysiology of prostate cancer in African-American men. J Urol. 2007;177(2):444449.

3. Akbal C, Tinay İ, Şimşek F, Turkeri LN. Erectile dysfunction following radiotherapy and brachytherapy for prostate cancer:pathophysiology, prevention and treatment. Intern Urol Nephrol. 2008;40(2):355-363.

4. Teras LR, DeSantis CE, Cerhan JR, Morton LM, Jemal A, Flowers CR. US lymphoid malignancy statistics by World Health Organization subtypes. CA Cancer J Clin. 2016;66(6):443-459. doi: 10.3322/caac.21357.

5. Jemal A, Tiwari RC, Murray T, Ghafoor A, Samuels A, Ward E, et al. Cancer statistics. CA Cancer J Clin. 2004;54(1):8-29.

6. Barve A, Khor TO, Nair S, Reuhl K, Suh N, Reddy B et al. Gamma-tocopherol-enriched mixed tocopherol diet inhibits prostate carcinogenesis in TRAMP mice. Int J Cancer. 2009;124:1693-1699. doi: 10.1002/ijc.24106.

7. Karan D, Thrasher JB, Lubaroff, D. Prostate cancer: genes, environment, immunity and the use of immunotherapy. Prostate Cancer Prostatic Dis. 2008;11(3), 230. doi: 10.1038/ pcan.2008.3.

8. Karan D, Dubey S. From inflammation to prostate cancer: the role of inflammasomes. Adv Urol. 2016;2016:3140372. doi: $10.1155 / 2016 / 3140372$

9. Lee J, Demissie K, Lu SE, Rhoads GG. Cancer incidence among Korean-American immigrants in the United States and native Koreans in South Korea. Cancer Control. 2007;14(1):78-85.

10. Li W, Yue W, Zhang L, Zhao X, Ma L, Yang X, Gu M. Polymorphisms in GSTM1, CYP1A1, CYP2E1, and CYP2D6 
are associated with susceptibility and chemotherapy response in non-small-cell lung cancer patients. Lung. 2012;190(1):9198. doi: 10.1007/s00408-011-9338-8.

11. Han XF, Ren JL, Hu LM, Chen FR, Xu KX. Prevalence of benign prostatic hyperplasia in Pingliang, Gansu: investigation and clinical analysis. Zhonghua Nan Ke Xue. 2013;19(4):324-7.

12. Krieger JN, Lee SW, Jeon J, Cheah PY, Liong ML, Riley DE. Epidemiology of prostatitis. Int J Antimicrob Agents. 2008;31:85-90. doi: 10.1016/j.ijantimicag.2007.08.028.

13. Hua VN, Schaeffer AJ. Acute and chronic prostatitis. Med Clin North Am. 2004;88(2):483-494.

14. Huh JS, Kim YJ, Kim SD. Prevalence of benign prostatic hyperplasia on Jeju Island: analysis from a crosssectional community-based survey. World J Mens Health. 2012;30(2):131-137. doi: 10.5534/wjmh.2012.30.2.131.

15. Saigal CS, Joyce G. Economic costs of benign prostatic hyperplasia in the private sector. J Urol. 2005;173(4):13091313.

16. Fukuta F, Masumori N, Mori M, Tsukamoto T. Natural history of lower urinary tract symptoms in Japanese men from a 15-year longitudinal community-based study. BJU Int. 2012;110(7):1023-1029. doi.org/10.1111/j.1464410X.2011.10866.X

17. Nahata A, Dixit VK. Ameliorative effects of stinging nettle (Urtica dioica) on testosterone-induced prostatic hyperplasia in rats. Andrologia. 2012;44:396-409. doi: 10.1111/j.14390272.2011.01197.x.

18. Pavone C, Abbadessa D, Tarantino ML, Oxenius I, Laganà A, Lupo A, et al. Associating Serenoa repens, Urtica dioica and Pinus pinaster. Safety and efficacy in the treatment of lower urinary tract symptoms. Prospective study on 320 patients. Urol J. 2012;77(1):43-51. doi. org/10.1177/039156031007700108.

19. Lopatkin N, Sivkov A, Schläfke S, Funk P, Medvedev A, Engelmann U. Efficacy and safety of a combination of Sabal and Urtica extract in lower urinary tract symptoms-longterm follow-up of a placebo-controlled, double-blind, multicenter trial. Int Urol Nephrol. 2007;39(4):1137-1146.

20. Ferlay J, Shin HR, Bray F, Forman D, Mathers C, Parkin DM. Estimates of worldwide burden of cancer in 2008: GLOBOCAN 2008. Int J Cancer. 2008;127(12):2893-917.

21. Merrill RM, Sloan A. Risk-adjusted incidence rates for prostate cancer in the United States. Prostate. 2012;72(2):1815 .

22. Grönberg H. Prostate cancer epidemiology. Lancet. 2003;361(9360):859-864.

23. Moradi B, Abbaszadeh S, Shahsavari S, Alizadeh M, Beyranvand $\mathrm{F}$. The most useful medicinal herbs to treat diabetes. Biomed Res Ther. 2018;5(8):2538-2551.

24. Naghdi N. Folklore medicinal plants used in liver disease: a review. Int J Green Pharm. 2018;12(03):11-13.

25. Carilla E, Briley M, Fauran F, Sultan CH, Duvilliers C. Binding of Permixon, a new treatment for prostatic benign hyperplasia, to the cytosolic androgen receptor in the rat prostate. J Steroid Biochem. 1984;20(1):521-523.

26. Sultan C, Terraza A, Devillier C, Carilla E, Briley M, Loire $\mathrm{C}$, et al. Inhibition of androgen metabolism and binding by a liposterolic extract of "Serenoa repens B" in human foreskin fibroblasts. J Steroid Biochem. 1984;20(1):515-519.

27. Crimi A, Russo A. Extract of Serenoa repens for the treatment of the functional disturbances of prostate hypertrophy. Med Praxis. 1983;4:47-51.
28. Berry SJ, Coffey DS, Walsh PC, Ewing LL. The development of human benign prostatic hyperplasia with age. J Urol. 1984;132(3):474-479.

29. Uberti E, Martinelli EM, Pifferi G, Gagliardi L. HPLC analysis of n-docosyl ferulate in Pygeum africanum extracts and pharmaceutical formulations. Fitoterapia. 1990;61(4):342347.

30. Golshan A, Mojdekanloo M, Bibak B, Kamali H. Reviews on natural products and medicinal plants role in prevention and treatment of cancer and benign hyperplasia of prostate. J North Khorasan Uni Med Sci. 2013;4(5):125-136.

31. Helzlsouer KJ, Huang HY, Alberg AJ, Hoffman S, Burke A, Norkus EP, Comstock GW. Association between $\alpha$-tocopherol, $\gamma$-tocopherol, selenium, and subsequent prostate cancer. J Natr Cancer Inst. 2000;92(24):2018-2023.

32. Colpi G, Farina U. Studio Dell' Attività Dell' Estratto Cloroformio Di Corteccia Di Pygeum Africanum Nella Terapia Della Sindrome Ostruttiva Uretrale Da Prostatopatia Non Cancerosa. Urol J. 1976;43(5):441-448.

33. Yasumoto R, Kawanishi H, Tsujino T, Tsujita M, Nishisaka $\mathrm{N}$, Horii A, et al. Clinical evaluation of long-term treatment using cernitin pollen extract in patients with benign prostatic hyperplasia. Clin Ther. 1995;17(1):82-87.

34. Buck AC, Cox R, Rees RWM, Ebeling L, John A. Treatment of outflow tract obstruction due to benign prostatic hyperplasia with the pollen extract cernilton: a double-blind, placebocontrolled study. Br J Urol. 1990;66(4):398-404.

35. Dutkiewicz S. Usefulness of Cernilton in the treatment of benign prostatic hyperplasia. Int Urol Nephrol. 1996;28(1):49-53.

36. Pfeifer BL, Pirani JF, Hamann SR, Klippel KF. PC-SPES, a dietary supplement for the treatment of hormone-refractory prostate cancer. BJU Int. 2000;85(4):481-485.

37. Mathewson-Chapman M. Pelvic muscle exercise/biofeedback for urinary incontinence after prostatectomy: an education program. J Cancer Educ. 1997;12(4):218-223.

38. Yu CL, Tsai MH. Fetal fetuin selectively induces apoptosis in cancer cell lines and shows anti-cancer activity in tumor animal models. Cancer Let. 2001;166(2):173-184.

39. Evans BAJ, Griffiths K, Morton MS. Inhibition of $5 a$-reductase in genital skin fibroblasts and prostate tissue by dietary lignans and isoflavonoids. J Endocrinol. 1995; 147(2):295-302.

40. Pollard M, Luckert PH. Influence of isoflavones in soy protein isolates on development of induced prostate-related cancers in L-W rats. Nutr Cancer. 1997;28(1):41-5.

41. Peterson G, Barnes S. Genistein and biochanin A inhibit the growth of human prostate cancer cells but not epidermal growth factor receptor tyrosine autophosphorylation. Prostate. 1993;22(4):335-345.

42. Kappas A, Anderson KE, Conney AH, Pantuck EJ, Fishman J, Bradlow HL. Nutrition-endocrine interactions: induction of reciprocal changes in the delta 4-5 alpha-reduction of testosterone and the cytochrome P-450-dependent oxidation of estradiol by dietary macronutrients in man. Proc Natl Acad Sci. 1983;80(24):7646-7649.

43. Keefover-Ring K, Thompson JD, Linhart YB. Beyond six scents: defining a seventh Thymus vulgaris chemotype new to southern France by ethanol extraction. Flav Frag J. 2009;24(3):117-122.

44. Kim SK, Chung JH, Lee BC, Lee SW, Lee KH, Kim YO. Influence of Panax ginseng on alpha-adrenergic receptor of benign prostatic hyperplasia. Int Neurourol J. 
2014;18(4):179-186. doi: 10.5213/inj.2014.18.4.179.

45. Cole C, Burgoyne TH, Lee A, Stehno-Bittel L, Zaid G. Arum palaestinum with isovanillin, linolenic acid and $\beta$-sitosterol inhibits prostate cancer spheroids and reduces the growth rate of prostate tumors in mice. BMC Complement Altern Med. 2015;15:264. doi: 10.1186/s12906-015-0774-5

46. Sachan R, Kundu A, Jeon Y, Choi WS, Yoon K, Kim IS, et al. Afrocyclamin A, a triterpene saponin, induces apoptosis and autophagic cell death via the PI3K/Akt/mTOR pathway in human prostate cancer cells. Phytomedicine. 2018;51:139150. doi: 10.1016/j.phymed.2018.10.012.

47. Jahanban-Esfahlan R, Seidi K, Monfaredan A, ShafieIrannejad V, Abbasi MM, Karimian, A, Yousefi B. The herbal medicine Melissa officinalis extract effects on gene expression of p53, Bcl-2, Her2, VEGF-A and hTERT in human lung, breast and prostate cancer cell lines. Gene. 2017;613:14-19.

48. Kim JK, Kim JY, Kim HJ, Park KG, Harris RA, Cho WJ., et al. Scoparone exerts anti-tumor activity against DU145 prostate cancer cells via inhibition of STAT3 activity. PloS One. 2013;8(11):e80391. doi: 10.1371/journal.pone.0080391.

49. Chang C, Zhao W, Xie B, Deng Y, Han T, Cui Y, Yan J. Pao pereira extract suppresses castration-resistant prostate cancer cell growth, survival, and invasion through inhibition of NfאB signaling. Integr Cancer Ther. 2014;13(3):249-258. doi: $10.1177 / 1534735413510557$.

50. Yang JB, Khan M, He YY, Yao M, Li YM, Gao HW, et al. Tubeimoside-1 induces oxidative stress-mediated apoptosis and G 0/G 1 phase arrest in human prostate carcinoma cells in vitro. Acta Pharmacol Sin. 2016;37(7):950. doi: 10.1038/ aps.2016.34.

51. Wang HQ, Li DL, Lu YJ, Cui XX, Zhou XF, Lin WP, Zheng X. Anticancer activity of Acanthopanax trifoliatus (L) Merr extracts is associated with inhibition of NF-kB activity and decreased Erk1/2 and Akt phosphorylation. Asian Pac J Cancer Prev. 2014;15(21):9341-9346.

52. Huang ZH, Zheng HF, Wang WL, Wang Y, Zhong LF, Wu $\mathrm{JL}$, et al. Berberine targets epidermal growth factor receptor signaling to suppress prostate cancer proliferation in vitro. Mol Med Rep. 2015;11(3):2125-2128.

53. Dai Y, DeSano J, Qu Y, Tang W, Meng Y, Lawrence TS, Xu L. Natural IAP inhibitor Embelin enhances therapeutic efficacy of ionizing radiation in prostate cancer. Am J Cancer Res. 2011;1(2):128.

54. Ye F, Jiang S, Volshonok H, Wu J, Zhang DY. Molecular mechanism of anti-prostate cancer activity of Scutellaria baicalensis extract. Nutr Cancer. 2007;57(1):100-110.

55. Atmaca H, Bozkurt E. Apoptotic and anti-angiogenic effects of Salvia triloba extract in prostate cancer cell lines. Tumor Biol. 2016;37(3):3639-3646. doi: 10.1007/s13277-015-42082.

56. Dhandayuthapani S, Azad H, Rathinavelu A. Apoptosis induction by Ocimum sanctum extract in LNCaP prostate cancer cells. J Med Food. 2015;18(7):776-785. doi: 10.1089/ jmf.2014.0008.

57. Ryu NH, Park KR, Kim SM, Yun HM, Nam D, Lee SG, et al. A hexane fraction of guava leaves (Psidium guajava L.) induces anticancer activity by suppressing AKT/mammalian target of rapamycin/ribosomal p70 S6 kinase in human prostate cancer cells. J Med Food. 2012;15(3):231-241. doi: 10.1089/jmf.2011.1701.

58. Younis T, Khan MI, Khan MR, Rasul A, Majid M, Adhami
$\mathrm{VM}$, et al. Nummularic acid, a triterpenoid, from the medicinal plant Fraxinus xanthoxyloides, induces energy crisis to suppress growth of prostate cancer cells. Mol Carcinog. 2018. 57(10):1267-1277. doi: 10.1002/mc.22841.

59. Wang X, Fang G, Pang Y. Chinese medicines in the treatment of prostate cancer: from formulas to extracts and compounds. Nutrients.2018;10(3):283-288.

60. Komakech R, Kang Y, Lee JH, Omujal F. A review of the potential of phytochemicals from Prunus africana (Hook f.) kalkman Stem Bark for chemoprevention and chemotherapy of prostate cancer. Evid Based Complement Alternat Med. 2017;2017:3014019. doi: 10.1155/2017/3014019.

61. Sung DJ, Cho SB, Kim YH, Oh YW, Lee NJ, Kim JH, et al. Comparison of prostate-specific antigen adjusted for transition zone volume versus prostate-specific antigen density in predicting prostate cancer by transrectal ultrasonography. J Ultrasound Med. 2004;23(5);615-622. doi: $\quad$ 10.7863/jum.2004.23.5.615.

62. Tajallaie-Asl F, Mardani M, Shahsavari S, Abbaszadeh S. Menstruation phytotherapy according to iran ethnobotanical sources. J Pharm Sci. 2017;9(6):986-990.

63. Coulter ID, Hardy ML, Morton SC, Hilton LG, Tu W, Valentine D, et al. Antioxidants vitamin C and vitamin e for the prevention and treatment of cancer. J Gen Intern Med. 2006;21(7):735-744. doi: 10.1111/j.1525-1497.2006.00483.x.

64. Wang XF, Dong L, Zhao Y, Tomasetti M, Wu K, Neuzil J. Vitamin $\mathrm{E}$ analogues as anticancer agents:Lessons from studies with a-tocopheryl succinate. Mol Nutr Food. 2006;50(8):675-685. doi: 10.1002/mnfr.200500267.

65. Israel K, Yu W, Sanders BG, Kline K. Vitamin E succinate induces apoptosis in human prostate cancer cells: role for Fas in vitamin E succinate-triggered apoptosis. J Nutr Cancer. 2000;36(1):90-100. doi: 10.1207/S15327914NC3601_13.

66. Kirsh VA, Hayes RB, Mayne ST, Chatterjee N, Subar AF, Dixon LB, et al. Supplemental and dietary vitamin E, $\beta$-carotene, and vitamin $\mathrm{C}$ intakes and prostate cancer risk. J Natl Cancer Inst. 2006;98(4):245-254. doi: 10.1093/jnci/ djj050.

67. Coogan PF, Smith J, Rosenberg L. Statin use and risk of colorectal cancer. J Natl Cancer Inst. 2007;99(1):32-40. doi: 10.1093/jnci/djk003.

68. Ajith TA, Harikumar KB, Thasna H, Sabu MC, Babitha NV. Proapoptotic and antitumor activities of the HMG-CoA reductase inhibitor, lovastatin, against Dalton's lymphoma ascites tumor in mice. Clin Chim Acta. 2006;366(1-2):322328. doi: 10.1016/j.cca.2005.11.012.

69. Wada S, Satomi Y, Murakoshi M, Noguchi N, Yoshikawa T, Nishino H. Tumor suppressive effects of tocotrienol in vivo and in vitro. Cancer Let. 2005;229(2):181-191. doi: 10.1016/j. canlet.2005.06.036.

70. Zhivotosky B, Orrenius S. Assessment of apoptosis and necrosis by DNA fragmentation and morphological criteria. Curr Prog Cell Biol. 2001;12(1):18-3. Doi: 10.1002/0471143030.cb1803s12.

71. Shklar G. Mechanisms of cancer inhibition by anti-oxidant nutrients. Oral Oncol. 1998;34(1):24-29. doi: 10.1016/S13688375(97)00060-2.

72. Rajurkar NS, Damame MM. Mineral content of medicinal plants used in the treatment of diseases resulting from urinary tract disorders. Appl Radiat Isot. 1998;49(7): 773776. Doi: 10.1016/S0969-8043(97)00296-0. 